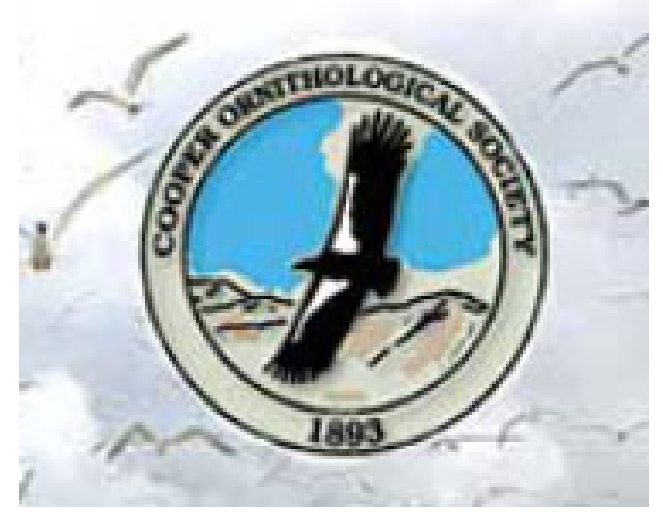

Site Fidelity of Black Brant Wintering and Spring Staging in the Strait of Georgia, British Columbia

Author(s): Eric T. Reed, Evan G. Cooch, R. Ian Goudie, Fred Cooke

Reviewed work(s):

Source: The Condor, Vol. 100, No. 3 (Aug., 1998), pp. 426-437

Published by: University of California Press on behalf of the Cooper Ornithological Society

Stable URL: http://www.jstor.org/stable/1369708

Accessed: 23/04/2012 22:37

Your use of the JSTOR archive indicates your acceptance of the Terms \& Conditions of Use, available at http://www.jstor.org/page/info/about/policies/terms.jsp

JSTOR is a not-for-profit service that helps scholars, researchers, and students discover, use, and build upon a wide range of content in a trusted digital archive. We use information technology and tools to increase productivity and facilitate new forms of scholarship. For more information about JSTOR, please contact support@jstor.org.

University of California Press and Cooper Ornithological Society are collaborating with JSTOR to digitize, preserve and extend access to The Condor. 


\title{
SITE FIDELITY OF BLACK BRANT WINTERING AND SPRING STAGING IN THE STRAIT OF GEORGIA, BRITISH COLUMBIA ${ }^{1}$
}

\author{
ERIC T. REED ${ }^{2}$ AND Evan G. COOCH \\ Department of Biological Sciences, Simon Fraser University, 8888 University Drive, Burnaby, B.C. V5A 1S6, \\ Canada, \\ e-mail: eric.reed@bio.ulaval.ca \\ R. IAN GoudIE ${ }^{3}$ \\ Canadian Wildlife Service, Pacific and Yukon Region, 5421 Robertson Road, RR\#1, Delta, B.C. V4K 3N2, \\ Canada \\ FRED COOKE \\ Department of Biological Sciences, Simon Fraser University, 8888 University Drive, Burnaby, B.C. V5A 1S6, \\ Canada
}

\begin{abstract}
Site fidelity has important implications for population genetics and dynamics. In birds, most studies have dealt with breeding ground fidelity, ignoring the fact that waterfowl mainly pair in winter or early spring. We used multiple observation data from a mark-resight study of Black Brant (Branta bernicla nigricans) to estimate fidelity to wintering and spring staging areas in Boundary Bay and Parksville-Qualicum, British Columbia. Site fidelity was low for winter residents but still indicated that Brant were faithful to Boundary Bay. Birds seen twice or more during any given winter had significantly higher site fidelity rates than those seen only once. The models for the spring period showed the presence of transients in both Boundary Bay and Qualicum. Birds seen for the first time in an area had a lower probability of returning to that area than birds seen in more than one year. Survival probability was significantly higher for Qualicum birds than for Boundary Bay birds. We concluded that prior knowledge of an area was an important determinant of site fidelity, and that low site fidelity levels were unlikely to lead to genetic substructuring of the population.
\end{abstract}

Key words: Black Brant, Branta bernicla nigricans, mark-resight, site fidelity, survival.

\section{INTRODUCTION}

Many species of birds and mammals exhibit long-term fidelity in the use of particular areas (Greenwood 1980). Site fidelity and dispersal have significant implications for the genetic structure and dynamics of populations. Site fidelity increases the isolation of local populations and thus can lead to significant genetic substructure among populations (Rockwell and Barrowclough 1987). Emigration and immigration affect population size as much as birth and death, and site fidelity, by increasing isolation, makes local populations more vulnerable to extinction (Levins 1970, Gadgil 1971).

Site fidelity to breeding areas has been widely studied in birds, but comparatively little atten-

\footnotetext{
${ }^{1}$ Received 20 February 1997. Accepted 11 February 1998.

${ }^{2}$ Current address: Département de Biologie and Centre d'Études Nordiques, Université Laval, Ste-Foy, Québec, G1K 7P4, Canada.

${ }^{3}$ Current address: 17 Waterford Bridge Road, StJohns, NF, A1E 1C5, Canada.
}

tion has been given to winter and spring staging site fidelity. In most species of North American waterfowl, pair bonds are formed on the wintering or spring staging grounds (Rohwer and Anderson 1988). Thus, fidelity to the location where pair formation occurs may be critical in understanding genetic structure (Robertson 1997). The timing of pair formation is not well known for most species of geese. However, it appears that most, but not all, pair bonds are formed during the winter and early spring (Owen et al. 1988). Geese are life-long monogamous birds, and they return to the wintering areas accompanied by their offspring (Prevett and MacInnes 1980, Reed 1993). They also acquire much of the nutrient reserves needed for egg formation and egg laying on the wintering and spring staging areas (Ankney 1984), making these areas critical for reproductive success. Geese in general are faithful to their wintering (Hestbeck et al. 1991, Percival 1991) and spring staging sites (Nilsson and Persson 1991), often returning year after year to the same roost and feeding areas (Raveling 1979). 


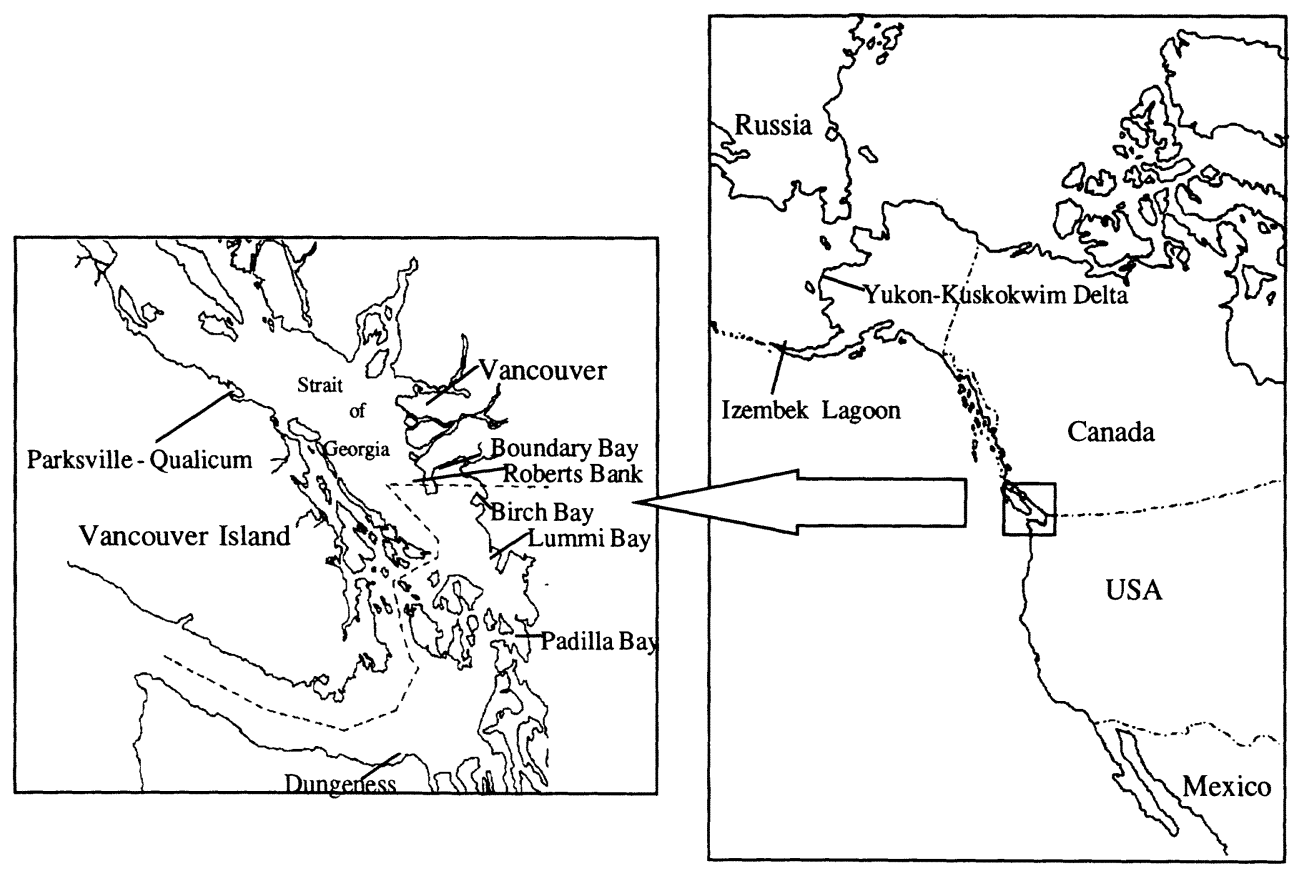

FIGURE 1. Locations of major wintering and spring staging sites for Black Brant in the Strait of Georgia, British Columbia, in relation to the Pacific coast of North America.

Black Brant (Branta bernicla nigricans) come from several distinct breeding areas distributed over much of the Arctic and subarctic coastal areas of Alaska, the Northwest Territories, the Yukon, and northeastern Russia (Reed et al. 1998). They mainly winter along the Pacific coast of North America, from Alaska to Baja California and the mainland of Mexico. Black Brant show high nest-site fidelity (Lindberg et al. 1995) and molting-site fidelity (Bollinger and Derksen 1996), but show little fidelity to their natal area (Lindberg and Sedinger 1997). Black Brant from all major breeding colonies mix on the molting grounds (Bollinger and Derksen 1996), increasing the probability of gene flow between interbreeding populations if mate choice occurs, or if some pairs are formed on the molting sites. Atlantic Brant (B. b. hrota), as well as other species of geese (such as Snow Geese Anser caerulescens, Cooke et al. 1975), from different nesting populations also widely overlap on their wintering range at both regional and local scales (K. Abraham, pers. comm.).

We used data from a resighting study of individually marked Black Brant in southwestern British Columbia to estimate probabilities of surviving and returning to wintering and spring staging areas. We modeled apparent survival and sighting probabilities, and used the estimates derived from the most parsimonious model to draw comparisons in site fidelity between seasons and, for the spring season, between locations. The origin of the birds observed also was evaluated. The results were used to make predictions about the causes and consequences of winter and spring staging site fidelity in Brant.

\section{METHODS}

Data on Black Brant wintering and staging in the Strait of Georgia have been collected annually on Vancouver Island (Parksville-Qualicum area) from 1989 to 1995 and in Boundary Bay, British Columbia from 1992 to 1996 (Fig. 1). During this study, approximately $8 \%$ of all Black Brant observed were marked with individually coded plastic leg bands by researchers on five major breeding or molting locations in Alaska, Russia, and the Northwest Territories (Sedinger et al. 1993, Ward et al. 1993, Bollinger and Derksen 1996). The rate of band loss was negligible (retention rate: $0.998 \pm 0.002$, Ward et al. 1997). Observations were conducted from shore using spotting scopes on most days when Black Brant were present in the area. 
Black Brant were usually present in ParksvilleQualicum from early March to mid-May and in Boundary Bay from early November to midMay. Information on age, pair and family status of marked birds also was collected. Because Brant show little sexual dimorphism in winter, we used information from the original banding records to assign sexes. On each visit, the maximum number of Brant present at Beach Grove, Boundary Bay, was estimated. Counts also were conducted in Parksville-Qualicum, but not with the same intensity. Observations in Boundary Bay were done at Beach Grove, whereas the Parksville-Qualicum data set contained observations from three separate locations: Parksville, French Creek, and Qualicum beach.

\section{STUDY POPULATIONS}

Brant were present in Boundary Bay during two seasons: winter and spring. Previous work indicated that there was no detectable turnover of Brant through the area in fall and that spring migrants did not appear in the study area before the second week of February (Reed 1997). Therefore, we defined winter residents as birds seen prior to 8 February, and spring migrants as birds seen on or after 8 February in any given year. Some birds seen for the first time on or after 8 February might have been present in the study area throughout the winter without being detected. The Parksville-Qualicum area was used by Brant only during the spring migration.

Both adult and juvenile birds were used in the analysis because some data sets were sparse. Only $4.9 \%$ of the marked individuals used in the analyses were juveniles, thus using them should not cause problems in model selection and parameter estimation. The years used to describe the winter period were those corresponding to the spring of that year. For example, the winter of 1993 refers to the November 1992 to February 1993 period.

\section{MODEL NOTATION}

Model notation followed Lebreton et al. (1992). All models were parameterized with survival and sighting probabilities defined as:

$\phi_{i}=$ apparent survival (hereafter survival); the probability that a bird alive and present in the study area during year $i$ survives (true survival rate) and is present (fidelity rate) in the area during year $i+1$,

$\mathrm{p}_{i}=$ probability that a bird is sighted in year $i$ given that it is alive and present in the study area during year $i$.

We used as a base model the Cormack-JollySeber (CJS) model (Cormack 1964, Jolly 1965, Seber 1965). In this model, survival $(\phi)$ and sighting (p) probabilities are time specific and the model is denoted as $\left(\phi_{t}, p_{t}\right)$. The subscript $(\mathrm{sex})$ was used when estimates for males and females were allowed to differ. The notation $\phi_{\mathrm{a} 2}$ refers to a two age-class effect on survival. Because we did not know true age but rather time since the first encounter in the study area, this model will be referred to as an encounter model with two classes. Thus, survival between the first year an individual was seen in the study area and the following year refers to survival for the first encounter class, whereas survival estimates in subsequent years refer to the second encounter class. Effects could be combined in an additive way [e.g., $\left(\phi_{\mathrm{a} 1+\mathrm{a} 2}\right)$, or with an interaction term where parameters are allowed to vary independently [denoted as $\left.\left(\phi_{\mathrm{a}^{*} *_{1}}\right)\right]$. Estimates also could be constrained to be a linear function of time, with $\left(\phi_{\text {allin*a2lin }}\right)$ or without $\left(\phi_{\text {allin }+ \text { a2lin }}\right)$ an interaction term. Sighting probabilities (p) followed the same notation. Finally, when no subscripts were used, we constrained the estimates to be constant over all effects.

In order to test for differences in survival and sighting probabilities between Boundary Bay and Qualicum during the spring, we used a combined analysis for the 3 years (1993-1995) in which we had data at both locations. Because the time periods used in the independent analyses differed (Boundary Bay: 1993-1996; Qualicum: 1989-1995), analyzing the data in this fashion, instead of directly comparing the estimates from the larger data sets, prevented confusing year and location effects. Thus, $\phi_{\mathrm{a}^{*} *_{1} *{ }_{0} \mathrm{cc}}$ was used to describe a model where survival was allowed to vary between encounter classes, years, and location. Year specificity was maintained in this analysis because we only had 3 years of data (i.e., two estimates for sighting rates and the 1st encounter class survival, one estimate for the 2 nd encounter class survival).

\section{MODEL SELECTION}

The model selection procedures followed Lebreton et al. (1992). As a first step, we tested the fit of the full time-dependent CJS model $\left(\phi_{t}, p_{t}\right)$ using the goodness-of-fit (GOF) tests provided by program RELEASE (Burnham et al. 1987) 
on males and females separately. RELEASE uses two tests (TEST2 and TEST3) to assess deviations from predictions based on the assumptions of the starting model. We paid particular attention to the TEST3.SR component of RELEASE, which compares, for each sighting occasion, the fates of animals entering the experiment with those seen previously. This test is useful in detecting true age effects, handling effects on survival (Brownie and Robson 1983), transients in the population (Pradel et al. 1997), or heterogeneity in capture (or sighting) rates (Loery et al. 1987). If TEST3.SR was rejected, we looked for systematic structural deviations in the chi-square table for each cohort. Random variation in observed frequencies relative to expected values may be due to extra binomial variation in the data, whereas a systematic trend in the pattern observed may suggest a biological factor. A variance inflation factor was used when extrabinomial variation was detected. When using the variation inflation factor, the LRT is transformed into an $F$-test and the standard errors and confidence intervals must be adjusted (Lebreton et al. 1992). If the model fits the data, the correction factor $(c)=1$. Excess variation in the data will result in a higher value of $c$. As a rule of thumb, values of $c>3$ indicate that the model structure is inadequate (Cooch et al. 1997).

Once a suitable general model had been determined by means of GOF tests, we proceeded to test the significance of the factors in the model and their interactions by sequential model fitting using program SURGE (Cooch et al. 1997). Likelihood ratio tests (LRT) were used to compare nested models, and the Akaike Information Criterion (AIC) was used to compare unnested models. We used, as suggested in Lebreton et al. (1992), an $\alpha$ level of 0.15 for identification of the general model and all subsequent testing.

\section{SITE FIDELITY ESTIMATES}

Survival estimates could be corrected to provide an index of site fidelity by dividing the estimate of survival from the models by the true annual survival rate, expressed as a percentage (Anderson and Sterling 1974). True annual survival of Black Brant was estimated as $84 \pm 3 \%$ from 1983 to 1993 (Ward et al. 1997).

\section{ORIGIN OF THE BIRDS}

We compared the proportion of individuals marked at different banding locations, using data from individual birds observed in Boundary Bay in winter and in spring separately, and those observed in Qualicum in the spring. Only comparisons within a year were possible because some banding operations were still active, whereas others had not been for a number of years, and we could only make comparisons between Boundary Bay and Qualicum for 1994 and 1995. Proportions were compared with $\chi^{2}$ tests.

\section{RESULTS}

\section{BOUNDARY BAY: WINTER 1993 TO 1996}

General model. A total of 305 sightings from 229 individually marked birds were recorded. We sighted 7 marked individuals in 1993, 108 in 1994, 83 in 1995, and 107 in 1996. Although we had insufficient data to calculate TEST2 and TEST3.SM of RELEASE, the overall TEST3.SR was nonsignificant (males: $\chi_{1}{ }_{1}=0.6, P>0.4$; females: $\chi^{2}{ }_{2}=1.5, P>0.4$ ), indicating homogeneity in sighting rates. Thus, the CJS model was used as a starting point.

Further models. There were no differences in survival [model (2) vs. (1), $P>0.5$ and model (4) vs. (3), $P=0.30$ ] and sighting rates [model (3) vs. (1), $P>0.8$, model (4) vs. (2), $P>0.8$ ] between males and females (Table 1). The omnibus test for overall variation between sexes also showed no significant differences between males and females [model (4) vs. (1), $P=0.4$ ], so the sexes were pooled for further analysis. Annual variation was not significant in either survival rates [model (5) vs. (4), $P>0.5$ ] or sighting rates [model (6) vs. (4), $P=0.26$ ]. Model (5) $\left[\phi, \mathrm{p}_{\mathrm{t}}\right]$ had the lowest AIC (302.9 vs. model $\left[\phi_{\mathrm{t}}, \mathrm{p}\right]:$ 303.8) between these two unnested models, and thus was considered as the most parsimonious, although the difference between the AIC values of the two models was small. We could not further reduce the model, as sighting rates varied significantly with time [model (7) vs. (5), $P=0.07]$. The constant survival rate was estimated, using model (5), at $0.42 \pm 0.04$, whereas the sighting rates were estimated at 0.87 $\pm 0.52,0.68 \pm 0.09$, and $1.00 \pm 0.00$ for the 1994, 1995, and 1996 season, respectively.

\section{BOUNDARY BAY: SPRING 1993 TO 1996}

General model. A total of 1,105 sightings from 959 individually marked birds were recorded in Boundary Bay during the spring period (134 sightings in 1993, 170 in 1994, 406 in 1995, and 395 in 1996). GOF test indicated rejection of the 
TABLE 1. Model selection for the resighting data of individually marked Black Brant for the winter period of 1992-1993 to 1995-1996 in Boundary Bay, British Columbia. The data are restricted to birds seen from 1 November to 8 February of each year ( $\mathrm{np}=$ number of parameters, DEV = deviance, AIC = Akaike's Information Criterion). The significance level is set at 0.15 and bold type highlights the most parsimonious model.

\begin{tabular}{|c|c|c|c|c|}
\hline Model & $\mathrm{np}$ & DEV & AIC & Comparison \\
\hline (1) $\phi_{\text {sex }^{*},}, p_{\text {sex }^{*} t}$ & 10 & 289.2 & 309.2 & \\
\hline (2) $\phi_{t}, p_{\operatorname{sex}^{*} t}$ & 8 & 290.0 & 306.0 & $\begin{array}{l}\text { sex variation on } \phi \\
\text { (2) vs. (1): } \chi_{2}^{2}=0.8, P=0.66 \\
\text { (4) vs. (3): } \chi_{2}^{2}=3.7, P=0.30\end{array}$ \\
\hline (3) $\phi_{\text {sex }^{*},}, p_{t}$ & 8 & 290.9 & 306.9 & $\begin{array}{l}\text { sex variation on } p \\
\text { (3) vs. }(1): \chi^{2}{ }_{2}=1.7, P=0.43 \\
\text { (4) vs. (2): } \chi^{2}{ }_{3}=4.6, P=0.21\end{array}$ \\
\hline (4) $\phi_{t}, p_{t}$ & 5 & 294.5 & 304.5 & $\begin{array}{l}\text { overall time variation on sex } \\
\text { (4) vs. }(1): \chi^{2}{ }_{5}=5.4, P=0.37\end{array}$ \\
\hline (5) $\phi, p_{t}$ & 4 & 294.9 & 302.9 & $\begin{array}{l}\text { time variation on } \phi \\
\text { (5) vs. (4): } \chi^{2}{ }_{1}=0.4, P=\mathbf{P . 5 5} \\
\text { (6) vs. (7): } \chi^{2}{ }_{2}=4.3, P=\mathbf{0 . 1 2}\end{array}$ \\
\hline (6) $\phi_{t}, \mathrm{p}$ & 4 & 295.8 & 303.8 & $\begin{array}{l}\text { time variation on } \mathrm{p} \\
\text { (6) vs. (4): } \chi^{2}{ }_{1}=1.3, P=0.26 \\
\text { (5) vs. (7): } \chi^{2}{ }_{2}=5.2, P=0.07\end{array}$ \\
\hline (7) $\phi, p$ & 2 & 300.1 & 304.1 & $\begin{array}{l}\text { (7) vs. (4): } \chi_{3}^{2}=5.6, P=0.13\end{array}$ \\
\hline
\end{tabular}

basic CJS model for males (TEST2 + TEST3: $\left.\chi^{2}{ }_{4}=23.9, P<0.001\right)$ and for females $\left(\chi^{2}{ }_{4}=\right.$ 7.5, $P=0.11)$. Significance in TEST3.SR $\left(\chi^{2}{ }_{2}\right.$ $=23.6, P<0.001$ for males and $\chi^{2}{ }_{2}=6.8, P$ $=0.03$ for females) suggested an encounter effect on survival. Although we had sparse data and could not fully assess the validity of this test, the GOF test indicated that model $\left[\phi_{\mathrm{a}^{*}}, \mathrm{p}_{\mathrm{t}}\right]$ fit the data (males: $\chi^{2}{ }_{2}=0.3, P>0.8$; females: $\left.\chi_{2}^{2}=0.7, P>0.7\right)$.

Further models. There were no sex differences in survival rates [model (2) vs. (1), $P>$ 0.6 , model (4) vs. (3), $P>0.6]$ or in sighting rates [model (3) vs. (1), $P>0.8$, model (4) vs. (2), $P>0.8$ ] (Table 2). The overall test of a sex effect on survival and sighting rates also was nonsignificant [model (4) vs. (1), $P>0.8$ ], so the data from both sexes could be pooled. A model where the survival rates for both encounter classes was constrained to be constant over time, while the sighting rates were allowed to vary (model $\left.\left[\phi_{\mathrm{a} 2}, \mathrm{p}_{\mathrm{t}}\right]\right)$, fitted significantly better than the initial time-dependent model [model (5) vs. (4), $P>0.4]$ (Table 2 ). The time variation on sighting rates was significant [model (6) vs. (4), $P<0.05]$, so the model could not be reduced

TABLE 2. Model selection for the resighting data on individually marked Black Brant for the spring period of 1992-1993 to 1995-1996 in Boundary Bay, British Columbia. The data are restricted to birds seen after 8 February of each year $(\mathrm{np}=$ number of parameters, DEV = deviance, AIC = Akaike's Information Criterion). The significance level is set at 0.15 and bold type highlights the most parsimonious model.

\begin{tabular}{|c|c|c|c|c|}
\hline Model & $\mathrm{np}$ & DEV & AIC & Comparison \\
\hline (1) $\phi_{\operatorname{sex}^{*}{ }^{2} *_{t}}, p_{\operatorname{sex}^{*} t}$ & 14 & 774.4 & 802.4 & \\
\hline (2) $\phi_{a 2 * t}, p_{\operatorname{sex}^{*} t}$ & 10 & 777.0 & 797.0 & $\begin{array}{l}\text { sex variation on } \phi \\
\text { (2) vs. (1): } \chi^{2}{ }_{4}=2.6, P=0.63 \\
\text { (3) vs. (4): } \chi^{2}{ }_{5}=3.0, P=0.69\end{array}$ \\
\hline (3) $\phi_{\operatorname{sex}^{*} 2^{*} *_{t}}, p_{t}$ & 12 & 774.8 & 798.8 & $\begin{array}{l}\text { sex variation on } p \\
\text { (3) vs. }(1): \chi^{2}{ }_{2}=0.4, P=0.83 \\
\text { (2) vs. (4): } \chi^{2}{ }_{3}=0.9, P=0.84\end{array}$ \\
\hline (4) $\phi_{\mathrm{a} 2^{*} \mathrm{t}}, \mathrm{p}_{\mathrm{t}}$ & 7 & 777.8 & 791.8 & $\begin{array}{l}\text { overall sex affect } \\
\text { (4) vs. (1): } \chi^{2}{ }_{7}=3.4, P=0.85\end{array}$ \\
\hline (5) $\phi_{\mathrm{a} 2}, \mathrm{p}_{\mathrm{t}}$ & 5 & 779.6 & 789.6 & $\begin{array}{l}\text { time variation on } \phi \\
\text { (5) vs. (4): } \chi^{2}{ }_{2}=1.7, P=\mathbf{0 . 4 3}\end{array}$ \\
\hline (6) $\phi_{\mathrm{a} 2 * t}, \mathrm{p}$ & 6 & 783.0 & 795.0 & $\begin{array}{l}\text { time variation on } p \\
\text { (6) vs. }(4): \chi^{2}{ }_{1}=5.2, P=0.02\end{array}$ \\
\hline
\end{tabular}


TABLE 3. Summary of estimates of annual survival $(\phi)$ and capture (p) probabilities for the spring migration data on the Black Brant in Boundary Bay (1993 to 1996) and Qualicum (1989-1995), British Columbia. The estimates are derived from model $\left[\phi_{\mathrm{a} 2}, \mathrm{p}_{\mathrm{t}}\right]$. Standard errors for the Qualicum estimates are corrected with the variance inflation factor.

\begin{tabular}{lcc}
\hline \hline & Boundary Bay & Qualicum \\
\hline Estimates of survival & & \\
1st encounter class & $0.28 \pm 0.04$ & $0.40 \pm 0.03$ \\
2nd encounter class & $0.70 \pm 0.09$ & $0.73 \pm 0.04$ \\
Recapture estimates & & \\
$\mathrm{p}_{2}$ & $0.45 \pm 0.09$ & $0.71 \pm 0.13$ \\
$\mathrm{p}_{3}$ & $0.70 \pm 0.08$ & $0.68 \pm 0.09$ \\
$\mathrm{p}_{4}$ & $0.53 \pm 0.03$ & $0.45 \pm 0.07$ \\
$\mathrm{p}_{5}$ & - & $0.49 \pm 0.06$ \\
$\mathrm{p}_{6}$ & - & $0.57 \pm 0.06$ \\
$\mathrm{p}_{7}$ & - & $0.70 \pm 0.07$ \\
\hline
\end{tabular}

any further. The survival rates estimated from model $\left[\phi_{\mathrm{a} 2}, \mathrm{p}_{\mathrm{t}}\right]$ were $0.28 \pm 0.04$ and $0.70 \pm$ 0.09 for the first and second encounter class, respectively, and sighting rates varied between $0.45 \pm 0.09$ and $0.70 \pm 0.08$ (Table 3 ).

\section{PARKSVILLE-QUALICUM: SPRING 1989 TO 1995}

General model. All GOF tests in program RELEASE were significant (TEST3: $\chi^{2}{ }_{12}=188.2$, $P<0.001$; TEST $\left.2: \chi_{8}^{2}=25.8, P<0.001\right)$. This result could not be attributed solely to extra binomial variation because systematic deviations in some of the component tests were apparent (e.g., all cells in TEST3.SR were skewed in the same direction). To minimize excess variation, we used only data from birds seen at Qualicum Beach. This site had the most sightings for the study period, and those sightings were distributed more evenly between years than those from Parksville or French Creek.

A total of 2,145 sightings from 1,609 marked individuals were recorded for Qualicum between 1989 and 1995 (83 sightings in 1989, 160 in 1990,306 in 1991, 257 in 1992, 331 in 1993, 379 in 1994, and 629 in 1995). GOF test for the Qualicum data still showed departure from the assumptions of CJS model (males: $\chi^{2}{ }_{17}=58.9$, $P<0.001$; females: $\chi^{2}{ }_{15}=69.2, P<0.001$ ). All cells in TEST3.SR varied significantly from predicted values for both sexes (males: TEST3.SR: $\chi^{2}{ }_{5}=38.9, P<0.001$; females: $\chi^{2}{ }_{5}$ $=42.0, P<0.001)$ and all were skewed in the same direction. TEST3.SM also was rejected (males: $\chi^{2}{ }_{5}=10.4, P=0.07$; females: $\chi^{2}{ }_{5}=$ 20.9, $P<0.001$ ).

The value of the variance inflation factor for the CJS model ( $c=3.47$ for males and 4.61 for females) indicated a significant departure from the assumptions of the CJS model. A two class encounter model also poorly fit the data (model $\left[\phi_{a^{*} *}, p_{t}\right]:$ GOF $\chi_{12}^{2}=20.0, P<0.07$ for males and $\chi^{2}{ }_{10}=27.2, P<0.01$ for females). However, the variance inflation factor for this model was $<3$ (males: $c=1.67$; females: $c=2.72$; total: $c=2.14)$.

Further models. The sex effect on survival [model (2) vs. (1), $P>0.75$; model (4) vs. (3), $P>0.75$ ] and sighting rates [model (3) vs. (1), $P>0.75$; model (4) vs. (2), $P>0.75$ ] was not significant (Table 4), so we pooled both sexes for further analyses. The interaction term (time $\mathrm{x}$ class) was not significant for survival [model (5) vs. (4), $P>0.75$ ] (Table 4). The estimated slopes for both encounter classes did not differ significantly from zero, so we constrained the survival estimates for the two classes to be constant over time [model (7) vs. (6), $P>0.75$ ]. Finally, a model where survival rates for both encounter classes and the sighting rates were constant (model $\left.\left[\phi_{\mathrm{a} 2}, \mathrm{p}\right]\right)$ failed to explain the data in a more parsimonious way [model (8) vs. (7), $P<0.10]$. The survival estimates and their corrected standard errors were $0.40 \pm 0.03$ and $0.73 \pm 0.04$ for the first and second class, respectively (Table 3 ). The estimated sighting rates varied from $0.45 \pm 0.07$ to $0.71 \pm 0.13$ (Table 3).

\section{DIFFERENCES BETWEEN SITES: SPRING MIGRATION}

We had only three sighting occasions (1993 to 1995), so we could not do any GOF testing on the starting model. Both the Qualicum and the Boundary Bay spring data sets showed encounter structure in the survival rates, so we used, as a starting model, model $\left[\phi_{a_{2} *_{*} *_{0 c}}, p_{\left.t^{*}\right|_{0 c}}\right]$. The effect of location on sighting rates was not significant $(P=0.20)$ (Table 5), however the low power of this test ( 3 years) and the small difference in AIC between this model and model $\left[\phi_{\mathrm{a}^{2} *_{\mathrm{t}} *_{\text {loc }}}, \mathrm{p}_{\left.\mathrm{t}^{*}\right|_{\mathrm{loc}}}\right.$ ] (AIC value difference: 0.4) prevented us from determining whether sighting rates were equal at both locations within years. However, the effect of location on survival rate was significant $(P<0.001)$, suggesting that true survival and/or site fidelity levels differed from 
TABLE 4. Model selection for the resighting data of individually marked Black Brant for the spring period of 1989 to 1995 in Qualicum, British Columbia. (np = number of parameters, DEV = deviance, AIC = Akaike's Information Criterion). The significance level is set at 0.15 and bold type highlights the most parsimonious model. Likelihood ratio tests are transformed into an $F$-test to account for extra-binomial variation in the data.

\begin{tabular}{|c|c|c|c|c|}
\hline Model & $\mathrm{np}$ & DEV & AIC & Comparison \\
\hline (1) $\phi_{\text {sex*a } 2 * t}, P_{\text {sex*t }^{*}}$ & 32 & $2,443.8$ & $1,206.0$ & \\
\hline (2) $\phi_{\mathrm{a} 2 *_{\mathrm{t}}}, \mathrm{p}_{\mathrm{sex} *_{\mathrm{t}}}$ & 22 & $2,452.6$ & $1,190.1$ & $\begin{array}{l}\text { sex effect on } \phi \\
\text { (2) vs. (1): } F_{10,32}=0.4, P>0.75 \\
\text { (3) vs. (4): } F_{11,32}=0.4, P>0.75\end{array}$ \\
\hline (3) $\phi_{\operatorname{sex}^{*}{ }^{*} 2_{t}}, p_{t}$ & 27 & $2,448.6$ & $1,198.2$ & $\begin{array}{l}\text { sex effect on } p \\
\text { (3) vs. (1): } F_{5,32}=0.5, P>0.75 \\
\text { (2) vs. (4): } F_{6,32}=0.3, P>0.75\end{array}$ \\
\hline (4) $\phi_{\mathrm{a} 2 * t}, \mathrm{p}_{\mathrm{t}}$ & 16 & $2,457.0$ & $1,180.1$ & $\begin{array}{l}\text { overall sex effect } \\
\text { (4) vs. (1): } F_{16.32}=0.4, P>0.75\end{array}$ \\
\hline (5) $\phi_{\mathrm{a} 1+\mathrm{a} 2}, \mathrm{p}_{\mathrm{t}}$ & 13 & $2,460.6$ & $1,175.8$ & $\begin{array}{l}\text { additivity on } \phi \\
\text { (5) vs. (4): } F_{3,32}=0.6, P>0.75\end{array}$ \\
\hline (6) $\phi_{\mathrm{a} l \mathrm{lin}}+\mathrm{a} 2 \mathrm{lin}, \mathrm{p}_{\mathrm{t}}$ & 9 & $2,464.3$ & $1,169.6$ & $\begin{array}{l}\text { linearity on } \phi \\
\text { (6) vs. (4): } F_{4,32}=0.4, P>0.75\end{array}$ \\
\hline (7) $\phi_{\mathrm{a} 2}, \mathrm{p}_{\mathrm{t}}$ & 8 & $2,464.5$ & $1,167.6$ & $\begin{array}{l}\text { time variation on } \phi \\
\text { (7) vs. }(6): F_{1,32}=0.1, P>0.75\end{array}$ \\
\hline (8) $\phi_{\mathrm{a} 2}, \mathrm{p}$ & 3 & $2,488.8$ & $1,169.0$ & $\begin{array}{l}\text { time variation on } \mathrm{p} \\
\text { (8) vs. (7): } F_{5,32}=2.3, P<0.10\end{array}$ \\
\hline
\end{tabular}

one site to the other. Model $\left[\phi_{\mathrm{a} 2 * *_{\mathrm{t}} \mathrm{loc}}, \mathrm{p}_{\mathrm{t}}\right]$ was the most parsimonious model. Estimates from model $\left[\phi_{\mathrm{a} 2 * *^{*}{ }_{0} \mathrm{oc}}, \mathrm{p}_{\mathrm{t}}\right]$ were consistent with the results from the larger data sets, as survival was higher for birds staging at Qualicum than those staging in Boundary Bay.

\section{SITE FIDELITY}

Boundary Bay: winter. The fidelity level derived for the winter was $50.0 \pm 7.1 \%$, meaning that half of the birds emigrated permanently from Boundary Bay each year. Due to the relatively short duration of our study, some temporary emigration could appear as permanent emigration, so this represents a minimum estimate of site fidelity.

When birds seen only once in any given year were compared to birds seen more than once, the most parsimonious model indicated that survival differed significantly between these two groups, but sighting rates did not (Table 6). Thus, individuals for which we had multiple sightings throughout a winter were more faithful to Boundary Bay in subsequent years than birds seen only once in a given year. In all, $56.3 \%$ of the birds were seen only once in Boundary Bay in any given winter during the study. There was no sex $\left(\chi^{2}{ }_{1}=0.7, P>0.4\right)$ or age $(Z=-0.4$, $P>0.05$, two-tailed) differences between these two groups. Analyzing the data in this fashion prevented estimating the 1993 survival rate because all the birds seen in the first year (1993) were only recorded once during that winter. The estimate of survival for birds seen only once in a year was $0.39 \pm 0.06$ and, for individuals seen twice or more in a year, $0.58 \pm 0.01$. Therefore, the site fidelity level for winter residents seen twice or more within a year was estimated at $69.2 \pm 4.0 \%$.

Boundary Bay and Qualicum: spring. Site fi-

TABLE 5. Between sites comparison for the spring period between 1993 and 1995. Boundary Bay and Qualicum, British Columbia, are compared. The significance level is set at 0.15 and bold type highlights the most parsimonious model.

\begin{tabular}{|c|c|c|c|c|}
\hline Model & $\mathrm{np}$ & DEV & AIC & Comparison \\
\hline $\begin{array}{l}\text { (1) } \phi_{\mathrm{a} 2 * \mathrm{t}^{*} \mathrm{loc}}, \mathrm{p}_{\mathrm{t} * \mathrm{loc}} \\
\text { (2) } \phi_{\mathrm{a} 2 * \mathrm{t} * \mathrm{loc}}, \mathbf{p}_{\mathrm{t}}\end{array}$ & $\begin{array}{l}8 \\
7\end{array}$ & $\begin{array}{l}1,437.9 \\
\mathbf{1}, \mathbf{4 3 9 . 5}\end{array}$ & $\begin{array}{l}1,453.9 \\
1,453.5\end{array}$ & $\begin{array}{l}\text { location variation on } \mathbf{p} \\
\text { (2) vs. (1): } \chi^{2}=1.6, P=\mathbf{P}=\mathbf{2 1}\end{array}$ \\
\hline (3) $\phi_{\mathrm{a} 2 * \mathrm{t}}, \mathrm{p}_{\mathrm{t}}$ & 4 & $1,465.4$ & $1,473.4$ & $\begin{array}{l}\text { location variation on } \phi \\
\text { (3) vs. (2): } \chi^{2}{ }_{3}=25.9, P<0.01\end{array}$ \\
\hline
\end{tabular}


TABLE 6. Comparison between individually marked Brant seen once in any given year (low fidelity group) and Brant seen more than once in a year (high fidelity group) during the winter in Boundary Bay, British Columbia. The significance level is set at 0.15 and bold type highlights the most parsimonious model.

\begin{tabular}{|c|c|c|c|c|}
\hline Model & $\mathrm{np}$ & DEV & AIC & Comparison \\
\hline (1) $\phi_{\mathrm{gr}}, \mathrm{p}_{\mathrm{t}^{*} \mathrm{gr}}$ & 6 & 311.2 & 323.2 & \multirow{4}{*}{$\begin{array}{l}\text { fidelity effect on } \phi \\
\text { (2) vs. (1): } \chi^{2}{ }_{1}=2.9, P=0.09 \\
\text { (3) vs. (4): } \chi^{2}{ }_{1}=6.8, P=0.01 \\
\text { fidelity effect on p } \\
\text { (3) vs. (1): } \boldsymbol{\chi}^{2}{ }_{2}=2.8, P=\mathbf{0 . 2 4}\end{array}$} \\
\hline (2) $\phi, p_{t^{*} g r}$ & 5 & 314.1 & 324.1 & \\
\hline (3) $\phi_{g r}, p_{t}$ & 4 & 314.0 & 322.0 & \\
\hline (4) $\phi, p_{t}$ & 4 & 320.8 & 328.8 & \\
\hline
\end{tabular}

delity for Boundary Bay spring transients was $31.0 \pm 7.7 \%$ between the time they were first seen in the area and the following year, and 82.1 $\pm 7.8 \%$ for those seen in subsequent years. Site fidelity at Qualicum was $45.1 \pm 7.0 \%$ for birds seen for the first time, and $87.0 \pm 8.6 \%$ for subsequent years. Although estimates in Boundary Bay were consistently lower, they did not differ significantly from those obtained at Qualicum.

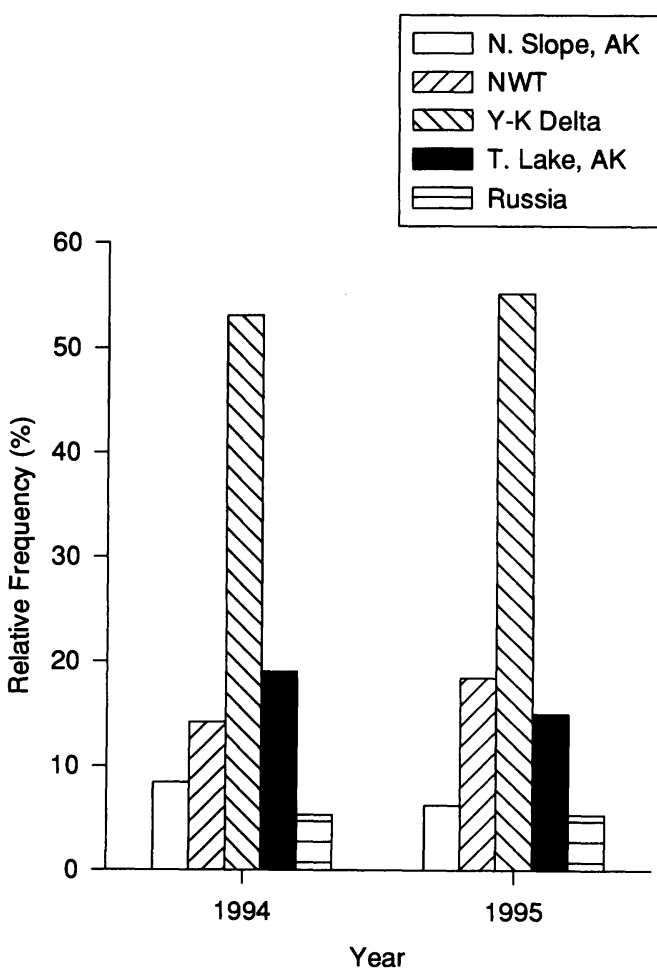

FIGURE 2. Origin of banded Brant observed in Boundary Bay and Qualicum in 1994 and 1995. The data from the winter and the spring are pooled.

\section{ORIGIN OF THE BIRDS}

Each of the five banding locations were represented equally between the winter and the spring period in Boundary Bay for the two years studied (winter vs. spring: both years $P>0.14$ ). The relative frequency of birds of different origin observed in spring migration did not differ significantly between Boundary Bay and the Qualicum area (both years: $P>0.5$ ). Individuals from all five marking locations mix on the wintering and spring staging areas (Fig. 2).

\section{DISCUSSION}

\section{WINTER SITE FIDELITY}

Our results show that Black Brant do not disperse randomly over the entire wintering range, but are faithful to some local areas. However, estimates of site fidelity for the winter residents $(50 \pm 7.1 \%)$ were lower than those derived from the second encounter class estimates for spring migrants and were closer to the estimates derived from the first encounter class in both sites. They also were low compared to estimates for other geese (e.g., Canada Goose Branta canadensis: 78.2, Raveling 1979; 56.2-88.9, Hestbeck et al. 1991; Barnacle Goose Branta leucopsis: 73.8-79.6, Percival 1991; Lesser Snow Goose A. c. caerulescens: 88 , Prevett and MacInnes 1980). Most of these estimates also will be biased low because only one of these studies (Hestbeck et al. 1991) controlled for detection and survival probabilities.

Bewick's Swans (Cygnus columbianus bewickii), wintering on the Severn Estuary in England, that returned in at least one subsequent winter had significantly longer previous attendance than those that did not return (Evans 1980). Our results corroborate these, as the Brant that had been seen only once in a year had 
lower probability of coming back to Boundary Bay. A large proportion of birds ( $>50 \%$ ) showed little site fidelity to Boundary Bay within and consequently between years.

Pradel et al. (1997) showed the presence of a large transient sub-population of Common Teal (Anas crecca) wintering in the Camargue, France. In their study, the sex-ratio of the transient component of the population fluctuated, and they hypothesized that unpaired birds were more likely to leave the area than paired individuals. Studies on waterfowl suggest that family units and paired birds are socially dominant for feeding (Lamprecht 1986, Black and Owen 1989), so that juveniles and unpaired birds might be more likely to disperse. Nonbreeders comprise $40-50 \%$ of the total population of Black Brant (Sedinger et al. 1994), which may explain the high movement rates we observed.

Brant with low site fidelity may have occupied winter territories centered some distance from our observation site, and we may have documented their fidelity to peripheral, rather than core areas. Difficulty in reading bands in winter from locations other than Boundary Bay precluded conducting a multistate analysis which would have quantified the amount of movement between wintering locations (Nichols et al. 1993). Site fidelity for winter residents seen twice or more in a year was high $(69.2 \pm$ $4.0 \%$ ), suggesting that there was a stable resident population of Black Brant wintering in Boundary Bay.

\section{SPRING FIDELITY}

Brant showed little first year fidelity for their spring stopover area (Boundary Bay: $31.0 \pm$ 7.7\%; Qualicum: $45.1 \pm 7.0 \%$ ), but those that returned in subsequent years exhibited high site fidelity (Boundary Bay: 82.1 \pm 7.0\%; Qualicum: $87.0 \pm 1.4 \%$ ). Thus, there was a large proportion of transients in the spring population in any given year, but the birds that did return to Boundary Bay and Qualicum in later years developed a traditional attachment to their spring staging site. The low proportion of juvenile birds in the samples $(4.9 \%)$ did not permit a comparison of site fidelity between adult and juvenile birds. This result emphasizes the importance of spring staging areas on the life history of Brant. Ebbinge and Spaans (1995) showed that Darkbellied Brent $(B . b$. bernicla) that had bigger fat reserves during spring migration brought more juveniles back to the wintering areas the following year, indicating that prior knowledge of an area may increase an individual's reproductive success if it allows it to forage more efficiently.

\section{COMPARISON BETWEEN SITES}

Survival estimates for the spring period in Boundary Bay were consistently lower than those derived from Qualicum, although the site fidelity estimates did not differ significantly. The difference in survival between Boundary Bay and Qualicum spring transients could be attributed to a variety of factors. The use of some juveniles in the analyses should not be responsible for the differences between these two sites as a higher proportion of juveniles were seen as adults in later years in Boundary Bay (22\%) than in Qualicum (11\%). This information suggests higher survival of Boundary Bay juveniles than Qualicum juveniles, which would lead to a larger difference in site fidelity than was estimated.

Given our sampling protocol, we cannot distinguish between effects of true survival and site fidelity in our survival estimates. However, it is notable that there is a 10-day hunting season on Brant in Boundary Bay (where spring migrants had lower survival) in early March, whereas the Parksville-Qualicum area is closed to Branthunting year round. Band returns show that both winter and spring transients are killed by hunters in Boundary Bay (Reed 1997). There is some evidence that hunting is an additive mortality factor in goose populations (Francis et al. 1992) and that survival estimates can be 5-10\% lower in hunted than in non-hunted populations, which is the magnitude of the difference observed between survival in Boundary Bay and Qualicum. Also, disturbance due to hunting might be enough for some birds to emigrate permanently from the area.

However, given that the hunting season is short, its effect on an entire life-cycle would not necessarily be detectable, and the potential factors affecting survival are not restricted to differences between spring staging areas (Ward et al. 1997). Also, we cannot separate completely true effects on survival with biases in the estimates as a result of heterogeneity due to the violation of some basic assumptions in our models (Prevot-Julliard et al. 1998). Studies with few sighting occasions are more susceptible to heterogeneity in sighting rates (Cooch and Reed, 
unpubl. data), and survival estimates of the first encounter class are negatively biased in the presence of heterogeneity (Prevot-Julliard et al. 1998), which could explain the situation encountered in our study. Comparative data from major wintering and spring staging grounds (e.g., Mexico and California) would be useful in determining the impact that hunting might have on site fidelity in Brant.

Unlike the Black Brant, the western high arctic Brant (a gray-bellied form of Pacific Brant) shows a high degree of segregation on their breeding, staging (Reed et al. 1989b), and wintering areas (Reed et al. 1989a). It therefore is not surprising that plumage characteristics (Boyd et al. 1988) and genetic structure (Shields 1990) of western high arctic Brant are different from Black Brant. There is, to our knowledge, no available information on segregation of breeding populations of Black or Gray-bellied Brant. However, Black Brant occupy a wide winter range and individuals from all natal and breeding localities mix on winter and spring staging areas (Fig. 2), and on molting grounds (Bollinger and Derksen 1996).

The higher site fidelity of birds which had longer previous attendance in our winter study area and the development of a traditional attachment to their spring staging sites suggest that ecological factors, such as knowledge of food and predator distribution, are important determinants of site fidelity in Black Brant. Black Brant are faithful to some degree to specific wintering and spring staging sites in British Columbia; however, large scale movements (Bellrose 1980), the presence of transient birds in spring staging populations, and high natal dispersal (Lindberg and Sedinger 1997) make genetic substructuring of the Pacific Flyway population unlikely.

Physical mixing does not equate to gene flow if individuals return to their breeding colonies or if pairing is assortative (Abraham et al. 1983), but there is some evidence in geese that individuals from different natal areas form pairs (Cooke et al. 1975). The mitochondrial DNAs of femalc Black Brant from four breeding areas in Alaska and the Northwest Territories were essentially homogeneous (Shields 1990), suggesting either a recent expansion of the breeding range or a high degree of gene flow among breeding populations. In view of our results, we hypothesize that an analysis based on mtDNAs of individuals from different wintering populations would yield similar results, and that low fidelity to winter and spring staging sites would facilitate gene flow and homogeneity. Mixing of populations during other periods of their life-cycle also might contribute to gene flow if some pairs are formed at these areas.

We provide data from an area that is used by a small proportion of the Pacific Flyway population of Black Brant and therefore we cannot make inferences for the entire Pacific Flyway population. We cannot rule out the possibility that interbreeding populations cover a much larger area than our study area and that those large aggregations of smaller wintering sub-units show different adaptations to the conditions encountered on the wintering areas. A large scale study on site fidelity rates from important wintering and spring staging areas would lead to a better understanding of population dynamics and gene flow in Black Brant. A better understanding of mate choice and the timing of pair formation would allow testing of specific hypotheses concerning the adaptive significance of site fidelity in geese.

\section{ACKNOWLEDGMENTS}

This research was supported by the British Columbia Waterfowl Society, the Canadian Wildlife Service, the Research Network Program, the Arctic Goose Joint Venture, and an NSERC grant to F. Cooke. We thank J. S. Sedinger, G. J. Robertson, A. Reed, R. McKelvey, N. A. M. Verbeek, T. D. Williams, M. S. Lindberg, and two anonymous reviewers for reading and suggesting many improvements to earlier drafts of the paper. We are particularly indebted to the volunteers who helped with the band reading, especially G. A. Poynter, R. Swanston, and J. Dussureault, and to all the people who have banded Brant and given us the permission to use them for our analyses.

\section{LITERATURE CITED}

Abraham, K. F., C. D. Ankney, ANd H. Boyd. 1983. Assortative mating by Brant. Auk 100:201-203.

Anderson, D. R., AND R. T. Sterling. 1974. Population dynamics of molting Pintail drakes banded in south central Saskatchewan. J. Wildl. Manage. 38:266-274.

ANKNEY, C. D. 1984. Nutrient reserve dynamics of breeding and molting Brant. Auk 101:361-370.

Bellrose, F. C. 1980. Ducks, geese and swans of North America. Stackpole Books, Harrisburg, PA.

BlaCK, J. M., AND M. OWEN. 1989. Agonistic behaviour in barnacle goose flocks: assessment, investment and reproductive success. Anim. Behav. 37: 199-209.

Bollinger, K. S., AND D. V. DeRksen. 1996. Demographic characteristics of molting Black Brant 
near Teshekpuk Lake, Alaska. J. Field Ornithol. 67:141-158.

Boyd, H., L. S. Maltby, and A. ReEd. 1988. Differences in the plumage patterns of Brant breeding in High Arctic Canada. Can. Wildl. Serv. Prog. Note 174.

BRownie, C., AND D. S. RoBson. 1983. Estimation of time-specific survival rates from tag-resighting samples: a generalization of the Jolly-Seber model. Biometrics 39:437-453.

Burnham, K. P., D. R. Anderson, G. C. White, C. Brownie, AND K. H. Pollock. 1987. Design and analysis methods for fish survival experiments based on release-recapture. Am. Fish. Soc. Monogr. 5.

CoOch, E. G., R. Pradel, ANd N. Nur. 1997. A practical guide to mark-recapture analysis using SURGE. 2nd ed. Centre d'Écologie Fonctionnelle et Évolutive-CNRS, Montpellier, France.

$\rightarrow$ Cooke, F., C. D. Macinnes, And J. P. Prevett. 1975. Gene flow between breeding populations of Lesser Snow Geese. Auk 92:493-510.

CORMACK, R. M. 1964. Estimates of survival from the sighting of marked animals. Biometrika 51:429438.

$\rightarrow$ Ebbinge, B. S., AND B. SpaAns. 1995. The importance of body reserves accumulated in spring staging areas in the Temperate Zone for breeding in Darkbellied Brent geese Branta $b$. bernicla in the higl Arctic. J. Avian Biol. 26:105-113.

Evans, M. E. 1980. The effects of experience and breeding status on the use of a wintering site by Bewick's Swan Cygnus columbianus bewickii. Ibis $122: 287-297$.

Francis, C. M., M. H. Richards, F. CoOKe, AND R. F. ROCKWELL. 1992. Long-term changes in survival rates of Lesser Snow Geese. Ecology 73:13461362.

GADGIL, M. 1971. Dispersal: population consequences and evolution. Ecology 52:253-261.

$\rightarrow$ Greenwood, P. J. 1980. Mating systems, philopatry and dispersal in birds and mammals. Anim. Behav. 28:1140-1162.

Hestbeck, J. B., J. D. Nichols, AND R. A. Malecki. 1991. Estimates of movement and site fidelity using mark-sighting data of wintering Canada Geese. Ecology 72:523-533.

Jolly, G. M. 1965. Explicit estimates from capturerecapture data with both death and immigrationstochastic models. Biometrika 52:225-247.

LAMPRECHT, J. 1986. Structure and causation of the dominance hierarchy in a flock of Bar-headed Geese (Anser indicus). Behaviour 96:24-48.

Lebreton, J.-D., K. P. Burnham, J. Clobert, and D. R. ANDERSON. 1992. Modeling survival and testing biological hypotheses using marked animals: a unified approach with case studies. Ecol. Monogr. 62:67-118.

LEVINS, R. 1970. Extinction, p. 77-107. In M. Gesternhaber [ed.], Some mathematical problems in biology. Am. Math. Soc., Providence, RI.

LindBerG, M. S., AND J. S. Sedinger. 1997. Ecological consequences of nest site fidelity in Black Brant. Condor 99:25-38.
Lindberg, M. S., J. S. Sedinger, And E. A. Rexstad. 1995. Estimating nest site fidelity of adult female black brant with multi-state modeling and geographic information systems. J. Appl. Stats. 22: 725-735.

Loery, G., K. H. Pollock, J. D. Nichols, AND J. E. HiNES. 1987. Age-specificity of Black-capped Chickadee survival rates: analysis of capture-recapture data. Ecology 68:1038-1044.

Nichols, J. D., C. Brownie, J. E. Hines, K. H. PolLOCK, AND J. B. HESTBECK. 1993. The estimation of exchanges among populations or subpopulations, p. 265-280. In J.-D. Lebreton and P. M. North [eds.], The use of marked individuals in the study of bird population dynamics: models, methods, and software. Birkhauser Verlag, Berlin.

Nilsson, L., AND H. Persson. 1991. Site tenacity and turnover rate of staging and wintering Bean Geese Anser fabalis in Southern Sweden. Wildfowl 42: 53-59.

Owen, M., J. M. Black, and H. Liber. 1988. Pair bond duration and timing of its formation in Barnacle Geese (Branta leucopsis), p. 23-38. In M. W. Weller [ed.], Waterfowl in winter. Univ. Minnesota Press, Minneapolis, MN.

Percival, S. M. 1991. The population structure of Greenland Barnacle Geese Branta leucopsis on the winter grounds on Islay. Ibis 133:357-364.

Pradel, R., N. Rioux, A. TAmisier, AND J.-D. LebreTON. 1997. Individual turnover among wintering Teal in Camargue: a mark-recapture study. J. Wildl. Manage. 61:816-821.

Prevett, J. P., AND C. D. MacInnes. 1980. Family and other social groups in Snow Geese. Wildl. Monogr. 71:1-46.

Prevot-Julliard, A-C., J.-D. Lebreton, and R. PraDEL. 1998. Re-evaluation of adult survival of Black-headed Gulls (Larus ridibundus) in presence of recapture heterogeneity. Auk 115:85-95.

Raveling, D. G. 1979. Traditional use of migration and winter roost sites by Canada Geese. J. Wildl. Manage. 43:229-235.

REED, A. 1993. Duration of family bonds of Brent Geese Branta bernicla on the Pacific coast of North America. Wildfowl 44:33-38.

ReEd, A., M. A. Davison, AND D. K. KRAEge. 1989a. Segregation of Brent Geese Branta bernicla wintering and staging in Puget Sound and the Strait of Georgia. Wildfowl 40:22-31.

ReEd, A., R. Stehn, ANd D. Ward. 1989b. Autumn use of Izembek Lagoon, Alaska, by Brant from different breeding areas. J. Wildl. Manage. 53: $720-725$.

Reed, A., D. H. Ward, D. V. Derksen, ANd J. S. SeDINGER. 1998. Brant (Branta bernicla). In A. Poole and F. Gill [eds.], The birds of North America, No. 337. The Academy of Natural Sciences, Philadelphia, and The American Ornithologists' Union, Washington, DC.

REED, E. T. 1997. Migration patterns and philopatry of the Black Brant (Branta bernicla nigricans) in the Strait of Georgia, British Columbia. M.Sc. thesis, Simon Fraser Univ., Burnaby, British Columbia, Canada. 
Robertson, G. J. 1997. Pair formation, mating system, and winter philopatry in Harlequin Ducks. Ph.D. diss., Simon Fraser Univ., Burnaby, British Columbia, Canada.

Rockwell, R. F., AND G. F. BARrowclough. 1987. Gene flow and the genetic structure of populations, p. 223-255. In F. Cooke and P. A. Buckley [eds.], Avian genetics. Academic Press, London.

RoHWER, F. C., AND M. G. ANDERSON. 1988. Femalebiased philopatry, monogamy, and the timing of pair formation in migratory waterfowl. Current Ornithol. 5:187-221.

Seber, G. A. F. 1965. A note on the multiple recapture census. Biometrika 52:249-259.

Sedinger, J. S., C. J. Lensink, D. H. WARD, R. M. ANTHONY, M. L. WEGE, AND G. V. BYRD. 1993. Current status and recent dynamics of the Black
Brant Branta bernicla breeding population. Wildfowl 44:49-59.

SEDINGER, J. S., D. H. WARD, R. M. ANTHONY, D. V. Derksen, C. J. Lensink, K. S. Bollinger, AND N. K. DAWE. 1994. Management of Pacific Brant: population structure and conservation issues. Trans. 59th No. Am. Wildl. Natur. Resour. Conf. 50-62.

SHIELDS, G. F. 1990. Analysis of mitochondrial DNA of Pacific Black Brant (Branta bernicla nigricans). Auk 107:620-623.

Ward, D. H., D. V. DeRksen, S. P. Kharitonov, AND V. V. BARANYUK. 1993. Status of Pacific Black Brant Branta bernicla nigricans on Wrangel Island, Russian Federation. Wildfowl 44:39-48.

$\rightarrow$ Ward, D. H., E. A. Rexstad, J. S. Sedinger, M. S. LinDBERG, AND N. K. DAwE. 1997. Seasonal and annual survival of adult Pacific Brant. J. Wildl. Manage. 61:773-781. 